DOI: 10.46340/eppd.2020.7.6.43

Irakliy Hobechiya, legal attorney

ORCID ID: https://orcid.org/0000-0002-6475-0164

Lviv State University of Internal Affairs,

bar association "Hobechiya and Partners", Ukraine

\title{
THE CONCEPT AND SIGNS OF CIVIL LEGAL PERSONALITY OF LEGAL ENTITIES IN THE FIELD OF PROVIDING LEGAL SERVICES UNDER THE LEGISLATION OF UKRAINE
}

\author{
Іраклій Гобечія, адвокат \\ Львівський державний університет внутрішніх справ, \\ адвокатське об'єднання "Гобечія і партнери», Україна

\section{ПОНЯТТЯ ТА ОЗНАКИ ЦИВІЛЬНОЇ ПРАВОСУБ'ЄКТНОСТІ ЮРИДИЧНИХ ОСІБ У СФЕРІ НАДАННЯ ПРАВНИЧИХ ПОСЛУГ ЗА ЗАКОНОДАВСТВОМ УКРАЇНИ}

\begin{abstract}
Chapter II of the Constitution of Ukraine is devoted to the rights, freedoms and responsibilities of person and citizen. Among such rights an important place is occupied by the right guaranteed by Art. 55 of the Basic Law - the right to protection of rights and freedoms by the court. The article provides a detailed theoretical analysis of the concept and features of civil legal personality of legal entities in the field of legal services under the laws of Ukraine. Legal entities in the field of legal services under the laws of Ukraine are organizations (in any organizational and legal form) established and registered in the manner prescribed by the Law of Ukraine "On State Registration of Legal Entities, Individual Entrepreneurs and Public Associations" and in accordance with the requirements of special legislation governing the legal status of their specific type and scope of activity. Based on the results of the research recommendations has been developed in the scientific article for the purpose of improving the normative regulation of the analyzed relations. Keywords: legal personality, legal entity, legal services, bar association, law firm, advocate.
\end{abstract}

Постановка проблеми. Розділ II Конституції України ${ }^{1}$ присвячений правам, свободам та обов'язкам людини і громадянина. Серед таких прав важливе місце посідає право, гарантоване ст. 55 Основного закону, а саме - право на захист прав і свобод судом. Так, кожному закріплено конституційну гарантію прав: оскаржувати у судовому порядку рішення / дії / бездіяльність органів держаної влади та місцевого самоврядування, їхніх посадових і службових осіб; на звернення за захистом своїх прав до Уповноваженого Верховної Ради України з прав людини; на конституційну скаргу до Конституційного Суду України у визначеному законом порядку; на звернення до міжнародних судових установ чи міжнародних організацій, щодо яких в України $\epsilon$ членство чи участь, опісля використання усіх національних засобів юридичного захисту; на захист прав і свобод від протиправних порушень і посягань будь-якими засобами, що не заборонені законом. Крім цього, у ст. 29 Конституції України гарантовано, що кожен заарештований чи затриманий має право скористатися правничою допомогою захисника, а ст. 59 визначає право саме на професійну правничу допомогу.

Згідно з ст. 17 Закону України «Про виконання рішень та застосування практики Європейського суду 3 прав людини» ${ }^{2}$ передбачено застосування національними судами під час вирішення справ

\footnotetext{
${ }^{1}$ Конституиія Украӥни, 1996 (Верховна Рада України). Офіиійний сайт Верховної Ради України. $<$ https://zakon.rada.gov.ua/laws/show/254\%D0\%BA/96-\%D0\%B2\%D1\%80/conv\#Text> (2020, вересень, 27).

2 Закон про виконання рішень та застосування практики Європейського суду з прав людини, 2006 (Верховна Рада України). Офіиійний сайт Верховної Ради Украӥни. 〈https://zakon.rada.gov.ua/laws/show/3477-15/conv\#Text〉 (2020, вересень, 27).
} 
як джерела права Європейської конвенції з прав людини та практики Європейського суду з прав людини (далі- ССПЛ). Так, 31 липня 2003 року, ухвалюючи рішення по справі «Доран проти Ірландії» ${ }^{1}$ ССПЛ відзначив, що «ефективний засіб» передбачає як запобігання, припинення порушення, так і закріплення механізмів поновлення і відновлення порушених прав. У продовження цієї позиції, 17 липня 2008 року, за результатами розгляду справи «Каіч та інші проти Хорватії» ЄСПЛ було вказано, що для Європейської конвенції з прав людини було б неприйнятним, якби у ст. 13 містилася виключно декларація права на ефективний захист без практичного застосування.

Станом на сьогодні, незважаючи на те, що для надання професійної правничої допомоги в Україні діє адвокатура, монополія якої на судове представництво та на захист від кримінального обвинувачення слушно запроваджена i поки не скасована (хоча відповідний законопроект конституційних змін існує і верифікований Конституційним Судом України), надзвичайно поширеним $є$ надання юридичних послуг різноманітними суб'єктами як зі статусом, так і без статусу юридичної особи. Поряд з тим, не можна недооцінювати значення і суспільної важливості таких послуг, як і варто погодитися із необхідністю належного правового регулювання статусу суб'єктів їхнього надання. Вищеописані обставини обумовлюють та підтверджують актуальність дослідження поняття та ознак цивільної правосуб'єктності юридичних осіб у сфері надання правничих послуг за законодавством України.

Стан дослідження. У юридичній літературі $€$ низка досліджень, присвячених як загальнотеоретичним питанням правосуб'єктності, так i безпосередньо цивільної правосуб'єктності, зокрема і окремих організаційно-правових форм юридичних осіб у сфері надання адвокатських послуг. Серед науковців, котрі вивчали дану проблематику: С.С. Бичкова, С.М. Братусь, О.Б. Верба-Сидор, П.М. Рабінович, Є.А. Салєй, І.В. Спасибо-Фатєєва, Ю.М. Юркевич та інші.

Мета даної наукової статті полягає у здійсненні детального теоретичного аналізу поняття та ознак цивільної правосуб'єктності юридичних осіб у сфері надання правничих послуг за законодавством України, а також вироблення рекомендацій з метою удосконалення нормативної регламентації цих відносин.

Виклад основного матеріалу. У юридичній літературі досі не існує єдиної думки з приводу проблем правосуб'єктності, однак виокремлюють три найбільш поширені підходи до розуміння правосуб'єктності: 1) ототожнення правосуб'єктності та правоздатності; 2) правосуб'єктність як праводієздатність; 3) широке розуміння правосуб'єктності (включення до змісту поняття «правосуб' єктність» трьох елементів: «правоздатність», «дієздатність» та «правовий статус» або «права та обов'язки з правового статусу» чи «права і обов'язки, надані законом» у різних комбінаціях) $)^{3}$. Так, якщо С.М. Братусь стверджував, що «визнаючи окрему людину або колективне утворення особою, цим ми визнаємо за нею правоздатність. Правоздатність - це право бути суб'єктом прав і обов'язків. Правоздатність і правосуб'єктність - рівнозначні поняття» ${ }^{4}$, С.С. Бичкова вважає, що правосуб' єктність варто розглядати як передумову виникнення, набуття правового статусу i вона складається із правоздатності та дієздатності ${ }^{5}$, то О.Б. Верба-Сидор виводить так звану формулу правосуб’єктності: «правосуб' єктність = (здатність мати + здатність здійснювати $)$ х права та обов'язки 6 .

У зв'язку з цим, варто зазначити, що у судовій практиці також можна окреслити певні підходи щодо визначення змісту поняття «правосуб'єктність» юридичних осіб.

Так, 11 листопада 2008 року Верховний Суд України, розглянувши справу у зв'язку із винятковими обставинами за відповідною скаргою Управління Пенсійного фонду України одного із районів Житомирської області за адміністративним позовом О_1 до цього Управління, Обласного

\footnotetext{
${ }^{1}$ Case of Doran v Ireland (Application no. 50389/99), 2003 (European Court Of Human Rights). Cour Européenne Des Droits De L'homme <https://hudoc.echr.coe.int/fre\#\{"itemid":["001-61277"]\}> (2020, вересень, 27).

${ }^{2}$ Case of Caic' and others v Croatia 22014/04, 2008 (European Court Of Human Rights). Cour Européenne Des Droits De L'homme <https://hudoc.echr.coe.int/rus\#\{"itemid":["001-87640"]\}> (2020, вересень, 27).

${ }^{3}$ Рабінович, П. (ред.) (2019). Незалежність і юридична відповідальність суддів як гарантії верховенства права. Львів: Сполом, 8.

${ }^{4}$ Братусь, С. Н. (1950). Субьекты гражд. права. Курс советского гражданского права. Москва:

Государственное издательство юридической литературы, 8.

5 Бичкова, С. С. (2011). Цивільний процесуальний правовий статус осіб, які беруть участь у справах позовного провадження: монографія. Київ: Атіка, 33, 37, 42-53.

${ }^{6}$ Рабінович, П. (ред.) (2019). Незалежність і юридична відповідальність суддів як гарантії верховенства права: монографія. Львів: Сполом, 16.
} 
центру з нарахування та виплати пенсій і допомог про стягнення сум виплат та направляючи розгляд спору до Житомирського окружного адміністративного суду вказав, що «...суди ... не 3'ясували із застосуванням законодавчих актів, які визначають правосуб'єктність відповідачів, їх права та обов'язки усфері публічних відносин, а також чи є вони належними відповідачами за всіма заявленими вимогами...» ${ }^{1}$.

Також, вирішуючи численні справи за позовами до уповноважених осіб Фонду гарантування вкладів фізичних осіб на ліквідацію банків, Велика Палата Верховного Суду дійшла до висновків, що із моменту введення у банках тимчасових адміністрацій Фонд гарантування вкладів фізичних осіб одержує повноваження управлінських і контролюючих органів банків, котрі все ж зберігають власну правосуб'єктність юридичних осіб та є самостійними господарюючими суб'єктами до моменту завершення процедури їхньої ліквідації і внесення відповідних записів до Єдиного державного реєстру юридичних осіб, фізичних осіб-підприємців та громадських формувань. Тому, у цивільних спорах щодо неналежності виконання банківськими установами зобов'язань за договорами банківських вкладі опісля початку процедур виведення Фондом банків із ринку належними відповідачами $є$ саме банки, а не Фонд (наприклад, постанова Верховного Суду від 20 березня 2019 року у справі № 161/4985/172, постанова Верховного Суду від 20 березня 2019 року у справі

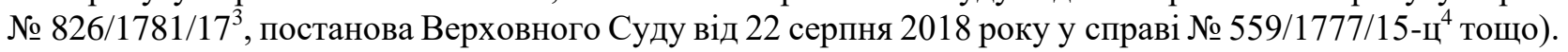

Отже, як бачимо, поняття правосуб'єктності трактується фактично у широкому розумінні та включено до нього як правоздатність і дієздатність, так і права та обов'язки. Саме такого підходу вважаємо за необхідне дотримуватися при дослідженні поняття та ознак цивільної правосуб'єктності юридичних осіб у сфері надання правничих послуг за законодавством України.

Слушною також є думка О.А. Сєрової, що поняття правосуб'єктності не можна розглядати у відриві від такого явища як легітимація суб'єкта права. На їі погляд, вірною є думка тих авторів, котрі розглядають правосуб' єктність як правовий стан особи в суспільстві, яким констатується факт визнання його суб'єктом існуючої системи права в цілому5.

Правосуб'єктність класифікують на види залежно від того, яке коло і який зміст передбачених нею прав і обов'язків. За цією ознакою розрізняють загальну, галузеву та спеціальну правосуб'єктність. Загальна правосуб'єктність - це здатність особи бути суб'єктом права взагалі. Галузева правосуб'єктність - це здатність особи бути, учасником правовідносин тієї чи іншої галузі права (виділяють, зокрема, правосуб'єктність політичну (державно-правову), громадянську, трудову, сімейну, процесуальну, цивільну і т.д.). Спеціальна правосуб'єктність - це здатність особи бути учасником лише певного кола правовідносин ${ }^{6}$.

При цьому, спеціальна правоздатність юридичної особи означає, що вона наділена лише тими цивільними правами, які передбачені в ії установчих документах і відповідають меті створення. В установчих документах в цьому випадку, як правило, вказують конкретні види діяльності, якими вправі займатися юридична особа. Інакше кажучи, спеціальна правоздатність визначається предметом діяльності юридичної особи, коли закріплення його в установчих документах $є$ обов'язковим у передбачених законодавством випадках. На відміну від осіб зі спеціальною правоздатністю юридичні особи, які наділені загальною правоздатністю, можуть займатися будь-якою діяльністю, що, однак, не може суперечить законодавству, як і мати будь-які цивільні права та обов'язки, що не протирічать нормативно-правовим актам ${ }^{7}$.

\footnotetext{
${ }^{1}$ Постанова у справі № 21-416во08, 2008 (Верховний Суд України). Сдиний держсавний реєстр судових рішень <http://www.reyestr.court.gov.ua/Review/3134164> (2020, вересень, 27).

2 Постанова у справі № 161/4985/17, 2019 (Верховний Суд України). Соиний державний реєстр судових рімень. <http://www.reyestr.court.gov.ua/Review/81573955> (2020, вересень, 27).

${ }^{3}$ Постанова у справі № 826/1781/17, 2019 (Верховний Суд України). Сдиний державний реєстр судових рімень. <http://www.reyestr.court.gov.ua/Review/80854749> (2020, вересень, 27).

${ }^{4}$ Постанова Верховного Суду у справі № 559/1777/15-u, 2018 (Верховний Суд України). Сдиний держсавний реєстр судових рішень. <http://www.reyestr.court.gov.ua/Review/78627871> (2020, вересень, 27).

${ }_{5}^{5}$ Серова, О. А. (2010). Понятие и виды правоспособности юридического лица. Вестник Самарской гуманитарной академии. Серия «Право», 1 (7), 73; Зинченко, С. А., Шапсулов, Д. Ю., Корх, С. Э. (1999).

Предпринимательство и статус его субъектов в современном российском праве. Ростов-на-Дону, 85.

${ }^{6}$ Lawbook.Online (2020). Виды правосубъектности. <https://lawbook.online/gosudarstva-prava-teoriya/vidyipravosubyektnosti-51644.html> (2020, вересень, 27).

${ }^{7}$ Салей, Е. А. (2020). Правоспособность юридических лиц по законодательству Республики Беларусь, 141. Law.Bsu.By<https://law.bsu.by/pub/29/Salei_1.doc> (2020, вересень, 27).
} 
У зарубіжній літературі окремими ознаками корпорації / юридичної особи визначають такі: $є$ суб'єктом права, відмінним від фізичної особи; та володіє безперервним правонаступництвом, що підтримується наступництвом нових осіб, які заміщують померлих або тих, що вибули в інший спосіб ${ }^{1}$ Зокрема, у 1897 році відбувся розгляд справи «Саломон проти Саломон і Ко Лтд», яка стосувалася законності обмеженої відповідальності однієї бенефіціарної компанії відповідно до законодавства про компанії, що мало наслідком створення концепції окремої правосуб'єктності юридичної особи. Цю ідею часто описують як фундаментальний принцип, і як метафору, $\mathrm{i}$ як судову реакцію ${ }^{2}$. Так, Саломон продав свій завантажувальний бізнес новоствореній компанії за 30000 фунтів стерлінгів. Його дружина, одна дочка та чотири сини одержали одну частку, вартістю по 1 фунту. Саломон одержав 23000 акцій вартістю по 1 фунт стерлінгів кожна та 10000 фунтів стерлінгів у компанії. Зобов'язання мали характер винагороди за передачу бізнесу. Згодом, коли компанія була ліквідована, вартість ії активів становила 6000 фунтів стерлінгів, а зобов'язання склали 17000 фунтів стерлінгів, з яких 10000 фунтів стерлінгів були перед незабезпеченими кредиторами. Незабезпечені кредитори стверджували, що Саломон і компанія $\epsilon$ однією і тією ж особою, і що компанія $є$ просто агентом для Саломона. Однак, компанія в трактуванні закону була окремою особою, незалежною від Саломона та не була його агентом. Саломон, хоча фактично був власником усіх акцій компанії, - також був забезпеченим кредитором і мав право на переважне погашення заборгованості переда ним. За результатами розгляду цісї справи було зроблено висновки, що шляхом реєстрації компанія набуває статусу окремої юридичної особи, і компанія визнається юридичною особою, окремою від своїх членів. Як наслідок, компанія може укладати контракти, подавати позов до суду, мати право власності на майно. Крім цього, компанія продовжує існувати, незважаючи на зміни в складі, а іiі акціонери можуть делегувати управління директорам. Цей принцип іноді називають так званою «завісою реєстрації» (корпоративною завісою), котру можна зняти за таких обставин, як необхідність захисту доходів, запобігання шахрайству тощо ${ }^{3}$.

Натомість, Цивільний кодекс України (далі - ЦК України) 4 чітко визначає поняття юридичної особи, з якого випливає, що обов'язковими ознаками юридичної особи як організації є: іiї створення та реєстрація у встановленому законом порядку; наявність власної цивільної правоздатності і дієздатності, а також відокремленого майна; можливість самостійно виступати в цивільному обороті, а також бути позивачем та відповідачем у суді ${ }^{5}$.

Відповідно до змісту ч. 4 ст. 91 ЦК України, виникнення цивільної правоздатності юридичних осіб пов'язане з моментом іiі створення, як і припинення, котре також відбувається з дня внесення відповідного запису до єдиного державного реєстру (Єдиного державного реєстру юридичних осіб, фізичних осіб-підприємців та громадських формувань).

Проаналізувавши коло суб'єктів ринку надання правничих послуг, можемо відмітити серед таких як фізичних осіб-підприємців, так і юридичних осіб різних організаційно-правових форм. Необхідно відзначити, що законодавець не обмежує форми господарювання у галузі надання правничої допомоги та надає свободу вибору заінтересованим учасникам відповідних відносин.

Врешті, 15 червня 2012 року Міністерство юстиції України затвердило Порядок та критерії залучення органами місцевого самоврядування юридичних осіб приватного права до надання безоплатної первинної правової допомоги ${ }^{6}$. Як вбачається зі змісту цього нормативно-правового акта, він визначає механізм та критерії залучення органами місцевого самоврядування юридичних осіб приватного права до надання безоплатної первинної правової допомоги, однак не обмежує їх коло якимись конкретними організаційно-правовими формами. При цьому, залучення юридичних осіб приватного права до надання безоплатної первинної правової допомоги на території відповідної

\footnotetext{
${ }^{1}$ Keenan, D. (ed.) (1987). Law for Business. Glasgow: Pitman Publishing, 1.

${ }^{2}$ Nicholas, J. (2020). Separate Legal Personality; Legal Reality and Metaphor, 217.

$<$ https://www.corteidh.or.cr/tablas/a16263.pdf> (2020, вересень, 27).

${ }^{3}$ Lawteacher (2019).The Nature of Legal Personality. 6th Aug <https://www.lawteacher.net/free-law-essays/ company-law/the-nature-of-legal-personality-law-essays.php> (2020, вересень, 27).

${ }^{4}$ Цивільний кодекс України, 2003 (Верховна Рада України). Відомості Верховної Ради України, 40, 3 жовт.

${ }^{5}$ Юркевич, Ю. М. (2017). Договірні форми об’єднань фізичних та юридичних осіб у цивільному праві

України: дисертаиія на здобуття наукового ступеня доктора юридичних наук. Львів: Львівський національний університет імені Івана Франка, 63-64.

${ }^{6}$ Наказ про затвердження Порядку та критеріїв залучення органами місиевого самоврядування юридичних осіб приватного права до надання безоплатної первинної правової допомоги, 2012 (Міністерство юстиції України). Офіційний сайт Верховної Ради України. 〈https://zakon.rada.gov.ua/laws/show/z0987-12\#n15> (2020, вересень, 27).
} 
адміністративно-територіальної одиниці здійснюється за результатами конкурсу проектів (програм) надання безоплатної первинної правової допомоги органом місцевого самоврядування на підставі укладеного договору. Участь у конкурсі можуть брати юридичні особи приватного права, які відповідно до свого статуту мають право надавати правову допомогу.

Якщо вести мову про класичні підприємницькі юридичні особи - господарські товариства (найбільшу частку серед яких займають товариства з обмеженою відповідальністю) та приватні підприємства, то вони наділені загальною правоздатністю. Відповідно, таким юридичним особам не заборонено здійснювати будь-яку діяльність в галузі права, зокрема види адвокатської діяльності, передбачені ст. 19 Закону України «Про адвокатуру та адвокатську діяльність», а саме пов’язані із: наданням правової інформації, консультацій і роз'яснень з правових питань, забезпеченням правового супроводу діяльності фізичних осіб і юридичних, органів державної та місцевого самоврядування чи держави; складенням скарг, заяв документів юридичного характеру; захистом прав, свобод і законних інтересів підозрюваного, обвинуваченого, підсудного, засудженого, виправданого, особи, стосовно якої передбачається застосування примусових заходів медичного чи виховного характеру або вирішується питання про їх застосування у кримінальному провадженні, особи, стосовно якої розглядається питання про видачу іноземній державі (екстрадицію), а також особи, яка притягається до адміністративної відповідальності під час розгляду справи про адміністративне правопорушення; надання правничої допомоги свідку в кримінальному провадженні; представництвом інтересів потерпілого під час розгляду справи про адміністративне правопорушення, прав і обов'язків потерпілого, цивільного позивача, цивільного відповідача у кримінальному провадженні тощо ${ }^{1} 3$ іншого боку, поряд 3 цим такі юридичні особи вправі одночасно здійснювати й інші види діяльності, наприклад у сфері будівництва, обслуговування, продажу тютюнових чи алкогольних виробів тощо. Зважаючи на зміст ст. 51 ЦК України, відповідно до якої до підприємницької діяльності фізичних осіб підлягають до застосування нормативно-правові акти, що регулюють підприємницьку діяльність юридичних осіб (якщо інше не встановлено законом чи не випливає із суті відносин), такими ж можливостями наділені суб'єкти підприємництва - фізичні особи-підприємці.

Що стосується таких організаційно-правових форм юридичних осіб як адвокатські об'єднання та адвокатські бюро, то вони, поряд із адвокатами-самозайнятими особами, $є$ організаційними формами адвокатської діяльності у відповідності до Закону України «Про адвокатуру та адвокатську діяльність». Законодавець окремо не регламентував їхнього спеціального правового статусу, обмежившись вказівкою, що державна реєстрація адвокатських об'єднань та адвокатських бюро здійснюється в порядку, встановленому Законом України «Про державну реєстрацію юридичних осіб, фізичних осіб-підприємців та громадських формувань»². Однак, на відміну від інших юридичних осіб, які здійснюють діяльність у сфері надання правничих послуг, адвокатські об'єднання та бюро повинні повідомляти відповідну раду адвокатів регіону про їх створення, реорганізацію, ліквідацію, зміну складу учасників впродовж трьох днів 3 дати внесення такої інформації до Єдиного державного реєстру юридичних осіб, фізичних осіб-підприємців та громадських формувань. Особливістю правового статусу адвокатських об'єднань та адвокатських бюро крім цього $є$ те, що їхніми засновниками (учасниками) можуть виступати виключно фізичні особи, що одержали свідоцтво про право на заняття адвокатською діяльністю. Це, своєю чергою, також породжує спеціальні правові наслідки, що пов'язані, зокрема, із таким:

- існує можливість відчуження на підставі цивільно-правових договорів частки в статутному капіталі адвокатських об'єднань та адвокатських бюро виключно на користь фізичних осіб, котрі одержали свідоцтво про право на заняття адвокатською діяльністю;

- існує можливість набуття частки у статутному капіталі адвокатських об'єднань та адвокатських бюро у порядку спадкового наступництва виключно фізичними особами, котрі одержали свідоцтво про право на заняття адвокатською діяльністю.

Свропейський Суд з прав людини опублікував аналітичний огляд практики «Привілеї юридичної професії», що містить низку рішень стосовно прав адвокатів і гарантій адвокатської діяльності у розумінні Свропейської конвенції за прав людини. Зокрема:

- у справі Бріто Ферріньо Бексіга Вілла-Нова проти Португалії заявник скаржилася, що ії банківські виписки були переглянуті в ході кримінального провадження у зв'язку з податковим

\footnotetext{
1 Закон про адвокатуру та адвокатську діяльність, 2012 (Верховна Рада України). Голос України, 148-149, 14 серп.

2 Закон про державну реєстрацію юридичних осіб, фізичних осіб-підприємиів та громадських формувань, 2003 (Верховна Рада України). Голос Украӥни, 115, 24 черв.
} 
шахрайством, порушеного проти неї. Вона стверджувала про порушення правил професійної конфіденційності, обов'язкових для неї через іiі професію адвоката. Суд постановив, що було порушення ст. 8 Свропейської конвенції з прав людини та зауважив, що перегляд банківських виписок заявника становив втручання у іiї право на повагу до професійної таємниці, яка належить до сфери приватного життя;

- у справі Копп проти Швейиарії, щзо стосувалася моніторингу телефонних ліній юридичних компаній Суд знайшов дивним той факт, що на практиці виконання цього завдання було доручено працівнику юридичного відділу пошти без нагляду з боку незалежного судді. Як адвокат, заявник не мав жодного захисту, надання якого передбачається верховенством права в демократичному суспільстві, що свідчить про порушення ст. 8 Європейської конвенції з прав людини;

- у справі Niemietz проти Німеччини, яка торкалася проблем обшуків та виїмок в адвокатських конторах та вдома, Суд нагадав, що посягання на професійну таємницю адвоката може мати наслідки для належного здійснення правосуддя і тим самим порушувати права, які гарантовані ст. 6 (право на справедливий суд) Європейської конвенції з прав людини ${ }^{1}$.

Однак, поряд із наявністю спеціального закону про адвокатську діяльність, особливим правовим статусом адвокатів як учасників відносин усфері надання правничої допомоги, додатковими гарантіями професійної адвокатської діяльності, чинним законодавством не встановлено правила, що адвокатські об'єднання та адвокатські бюро вправі здійснювати виключно діяльність, пов'язану із наданням юридичних послуг, хоча ст. 19 Закону України «Про адвокатуру та адвокатську діяльність» інші види діяльності, не забороненими законом, які може здійснювати адвокат обмежує саме адвокатськими послугами.

3 огляду на зміст ст. 7 Закону України «Про адвокатуру та адвокатську діяльність», адвокати адвокатських об'єднань та бюро не вправі здійснювати судово-експертну діяльність, нотаріальну діяльність тощо.

До адвокатів також пред’явлені підвищені вимоги. Зокрема:

- адвокатом може бути фізична особа, яка має повну вищу юридичну освіту, володіє державною мовою, має стаж роботи в галузі права не менше двох років, склала кваліфікаційний іспит, пройшла стажування (крім випадків, встановлених цим Законом), склала присягу адвоката України та отримала свідоцтво про право на заняття адвокатською діяльністю;

- не може бути адвокатом особа, яка: має непогашену чи незняту в установленому законом порядку судимість за вчинення тяжкого, особливо тяжкого злочину, а також нетяжкого злочину, за який призначено покарання у виді позбавлення волі; визнана судом недієздатною чи обмежено дієздатною; позбавлена права на заняття адвокатською діяльністю, - протягом двох років 3 дня прийняття рішення про припинення права на заняття адвокатською діяльністю; звільнена 3 посади судді, прокурора, слідчого, дізнавача, нотаріуса, з державної служби або служби в органах місцевого самоврядування за порушення присяги, вчинення корупційного правопорушення, - протягом трьох років 3 дня такого звільнення;

- адвоката може бути притягнуто до дисциплінарної відповідальності у порядку дисциплінарного провадження з підстав, передбачених законом (зокрема, дисциплінарним проступком адвоката $є$ : порушення вимог несумісності; порушення присяги адвоката України; порушення правил адвокатської етики; розголошення адвокатської таємниці або вчинення дій, що призвели до ії розголошення; невиконання або неналежне виконання своїх професійних обов'язків; невиконання рішень органів адвокатського самоврядування; порушення інших обов'язків адвоката, передбачених законом і т.п.

Порівнюючи з організаційними формами адвокатської діяльності у зарубіжних країнах, варто вказати, що, наприклад у Німеччині, учасниками партнерського товариства можуть бути представники таких професій, як адвокати, аудитори, податкові консультанти, патентні повірені; однією з умов створення адвокатського товариства з обмеженою відповідальністю $є$ дозвіл відповідної адвокатської палати; в адвокатському акціонерному товаристві в обов'язковому порядку повинна бути створена наглядова рада, а також існує заборона на залучення третіх осіб, які не $\epsilon$ представниками професії тощо ${ }^{2}$.

\footnotetext{
${ }^{1}$ Закон і Бізнес (2018). Гарантії адвокатської діяльності: ЄСПЛ навів ключові рішення <https://zib.com.ua/ua/print/131858-garantii_advokatskoi_diyalnosti_espl_naviv_klyuchovi_rishenn.html> (2020, вересень, 27).

2 Дерра, М. (2020). Адвокатура в Германии <https://zakon.ru/Tools/DownloadFileRecord/23439> (2020, вересень, 27). 
3 огляду на зазначене, а також беручи до уваги принципи адвокатської діяльності (верховенства права, законності, незалежності, конфіденційності та уникнення конфлікту інтересів), вважаємо за можливе зробити висновок, що адвокатські об’єднання та адвокатські бюро є юридичними особами приватного права зі спеціальною правосуб'єктністю та правом здійснювати виключно види адвокатської діяльності. Задля уникнення непорозумінь та недопущення неоднакового тлумачення пропонуємо закріпити відповідні положення у нормах Закону України «Про адвокатуру та адвокатську діяльність». Окремо необхідно також обмежити можливість залучення органами місцевого самоврядування юридичних осіб приватного права до надання безоплатної первинної правової допомоги виключно з-поміж адвокатських об'єднань, адвокатських бюро, інших юридичних осіб, що одержали дозвіл ради адвокатів відповідного регіону.

Досліджуючи поняття та ознаки цивільної правосуб'єктності юридичних осіб у сфері надання правничих послуг, необхідно зазначити, що згідно із законодавством України передбачено право окремих категорій осіб, що перебувають під національною юрисдикцією, на одержання безоплатної правової допомоги.

Відповідно до п. 1 ч. 1 ст. 1 Закону України «Про безоплатну правову допомогу», безоплатна правова допомога - правова допомога, що гарантується державою та повністю або частково надається за рахунок коштів Державного бюджету України, місцевих бюджетів та інших джерел ${ }^{1}$.

Зокрема, відповідно до ст. 12 названого Закону, органи місцевого самоврядування з врахуванням потреби територіальної громади можуть створити спеціалізовані установи 3 надання безоплатної первинної правової допомоги. Такі спеціалізовані установи $є$ неприбутковими організаціями, користуються правами юридичної особи, мають власні бланки, печатку із своїм найменуванням, фінансуються за рахунок коштів місцевих бюджетів та інших не заборонених законодавством джерел.

Згідно з Типовим Положенням про установу з надання безоплатної первинної правової допомоги, установа $є$ неприбутковою організацією, юридичною особою публічного права, має власні бланки, печатку із своїм найменуванням ${ }^{2}$. Варто згадати, що, критерієм, який закладений при поділі

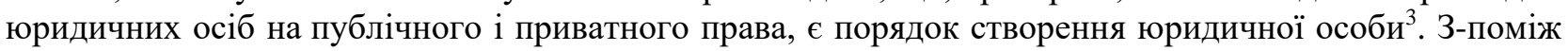
характеристик юридичних осіб публічного права у наукових джерелах, визначають, зокрема, наступні: $є$ публічно-правовим, не цивільно-правовим утворенням, призначенням якого є участь у цивільному обороті чи здійснення підприємницької та господарської діяльності; особливе цільове призначення - реалізація суспільних інтересів тощо 4 .

При цьому, вищезгадана установа відповідно до покладених на неї завдань: розглядає звернення осіб про надання безоплатної первинної правової допомоги; надає правову інформацію, консультації, роз'яснення з юридичних питань; складає документи правового характеру, за винятком документів процесуального характеру; надає допомогу в забезпеченні доступу особи до вторинної правової допомоги та медіації; виконує інформативні обов'язки згідно з Типовим положенням5 .

Відповідно до ст. 16 Закону України «Про безоплатну правову допомогу», Міністерство юстиції України утворює регіональні та місцеві центри з надання безоплатної вторинної правової допомоги, що $є$ територіальними відділеннями Координаційного центру з надання правової допомоги. Такі центри є неприбутковими організаціями, користуються правами юридичної особи, мають власні бланки, печатку із своїм найменуванням, фінансуються з Державного бюджету України та інших

\footnotetext{
1 Закон про безоплатну правову допомогу, 2011 (Верховна Рада України). Офіційний сайт Верховної Ради України. <https://zakon.rada.gov.ua/laws/show/3460-17/conv\#Text> (2020, вересень, 27).

${ }^{2}$ Наказ про затвердження Типового положення про установу з надання безоплатної первинної правової допомоги, 2012 (Міністерство юстиції України). Офіційний сайт Верховної Ради Украӥни

<https://zakon.rada.gov.ua/laws/show/z0474-12/conv\#Text> (2020, вересень, 27).

${ }_{3}^{3}$ Спасибо-Фатєєва, I. (2014). Юридичні особи за Цивільним кодексом України. Право України, 2, 71.

${ }^{4}$ Анпілогов, О. В. (2016). Структура реформування територіального та галузевого управління регіональним комплексом: адміністративно-правовий аспект: монографія. Київ, Логос, 218; Кисіль, Л. С. (2011).

Теоретичні питання адміністративної правосуб'єктності органів виконавчої влади. Збірник наукових праць: VI Міжнар. Науково-практичної конференції «Адміністративне право України: стан і перспективи розвитку», м. Київ, 23-24 вересня, 191-192; Чиркин, В. Е. (2006). Необходимо ли понятие юридического лица публичного права. Государство и право, 5, 23-24.

${ }^{5}$ Наказ про затвердження Типового положення про установу з надання безоплатної первинної правової допомоги, 2012 (Міністерство юстиції України). Офіційний сайт Верховної Ради Украӥни. <https://zakon.rada.gov.ua/laws/show/z0474-12/conv\#Text> (2020, вересень, 27).
} 
не заборонених законодавством джерел. Згідно з Положенням про центри 3 надання безоплатної вторинної правової допомоги, їхніми основними завданнями визначено підвищення правової свідомості, культури та освіченості населення (правопросвітництво); надання безоплатної первинної правової допомоги i безоплатної вторинної правової допомоги та забезпечення доступу до електронних сервісів Міністерства юстиції України ${ }^{1}$.

Отже, виходячи з наведеного, установи з надання безоплатної первинної правової допомоги та центри 3 надання безоплатної вторинної правової допомоги також $є$ юридичними особами зі спеціальною правосуб'єктністю. Також, органи виконавчої влади та органи місцевого самоврядування зобов'язані проводити особистий прийом осіб, які потребують безоплатної первинної правової допомоги, з питань, що належать до компетенції відповідного органу виконавчої влади чи органу місцевого самоврядування.

Висновки. Підсумовуючи та конкретизуючи вищевикладене, вважаємо за можливе зробити наступні висновки:

- юридичними особами у сфері надання правничих послуг за законодавством України $є$ організації у будь-якій організаційно-правовій формі, створені та зареєстровані у порядку, визначеному Законом України «Про державну реєстрацію юридичних осіб, фізичних осібпідприємців та громадських формувань» та відповідно до вимог спеціального законодавства, що регламентує правовий статус їх конкретного виду та сферу діяльності;

- правосуб'єктність юридичних осіб усфері надання правничих послуг необхідно розглядувати у широкому розумінні, включаючи у це поняття «правоздатність», «дієздатність» та «права та обов'язки 3 правового статусу» та саме такий підхід доцільно застосовувати при врегулюванні особливостей діяльності їхніх окремих видів у досліджуваній сфері;

- виокремлюючи ознаки цивільної правосуб'єктності юридичних осіб усфері надання правничих послуг, варто вказати, що такі суб'єкти можуть: бути юридичними особами приватного (наприклад, товариства з обмеженою відповідальністю) або публічного (наприклад, центри з надання безоплатної вторинної правової допомоги) права; бути наділені загальною (наприклад, приватні підприємства) або спеціальною (наприклад, адвокатські бюро) правоздатністю; бути регульованими спеціальним законом (наприклад, товариства з додатковою відповідальністю) або не мати такого регулювання на рівні окремого закону (наприклад, установи з надання безоплатної первинної правової допомоги); містити спеціальні вимоги до складу їхніх учасників (наприклад, повні товариства) або їх не мати (наприклад, акціонерні товариства) тощо. Відповідно цивільна правосуб'єктність таких юридичних осіб може бути загальною або спеціальною;

- у ході удосконалення чинного законодавства України, доцільно доповнити ст. 14 та ст. 15 Закону України «Про адвокатуру та адвокатську діяльність», закріпивши, що адвокатські бюро та адвокатські об'єднання не вправі здійснювати будь-якої діяльності, не пов'язаної із наданням правничої (правової) допомоги;

- ч. 5 ст. 12 Закону України «Про безоплатну правову допомогу» необхідно викласти в новій редакції наступного змісту: «5. Органи місцевого самоврядування можуть укладати з адвокатськими об'єднаннями, адвокатськими бюро, іншими юридичними особами, що одержали дозвіл ради адвокатів відповідного регіону, а також адвокатами, що здійснюють діяльність індивідуально, договори про надання на постійній або тимчасовій основі первинної правової (правничої) допомоги на території відповідної адміністративно-територіальної одиниці».

\section{References:}

1. Nicholas, J. (1993). Separate Legal Personality; Legal Reality and Metaphor, 217-228. $<$ https://www.corteidh.or.cr/tablas/a16263.pdf> (2020, September, 27). [in English].

2. Lawbook.Online (2020). Vidy pravosubyektnosti [Types of legal personality] $<$ https://lawbook.online/gosudarstva-prava-teoriya/vidyi-pravosubyektnosti-51644.html> (2020, September, 27). [in Russian].

3. Lawteacher (2019).The Nature of Legal Personality. 6th Aug <https://www.lawteacher.net/free-law-essays/ company-law/the-nature-of-legal-personality-law-essays.php> (2020, September, 27). [in English].

4. Keenan, D. (ed.) (1987). Law for Business. Glasgow: Pitman Publishing. [in English].

\footnotetext{
${ }^{1}$ Наказ про затвердження Положення про центти з надання безоплатної вторинної правової допомоги, 2012

(Міністерство юстиції України). Офіиіииний сайт Верховної Ради Украӥни.

<https://zakon.rada.gov.ua/laws/show/z1091-12/conv\#Text> (2020, вересень, 27).
} 
5. Anpilohov, O. V. (2016). Struktura reformuvannya terytorialnoho ta haluzevoho upravlinnya rehionalnym kompleksom: administratyvno-pravovyy aspekt: monohrafiya [The structure of reforming the territorial and sectoral management of the regional complex: administrative and legal aspect: a monograph]. Kyiv, Logos. [in Ukrainian].

6. Kysil, L. Ye. (2011). Teoretychni pytannya administratyvnoyi pravosubyektnosti orhaniv vykonavchoyi vlady [Theoretical issues of administrative legal personality of executive bodies]. Zbirnyk naukovykh prats: VI Mizhnar. Naukovo-praktychnoyi konferentsiyi Administratyvne pravo Ukrayiny: stan i perspektyvy rozvytku, $m$. Kyiv, 23-24 veresnya [Collection of scientific works: VI International. Scientific-practical conference Administrative law of Ukraine: state and prospects of development, Kyiv, September 23-24], 190-194. [in Ukrainian].

7. Chirkin, V. Ye. (2006). Neobkhodimo li ponyatiye yuridicheskogo litsa publichnogo prava [Is the concept of a legal entity under public law necessary]. Gosudarstvo i pravo [State and law], 5, 22-26. [in Russian].

8. Bychkova, S. S. (2011). Tsyvilnyy protsesualnyy pravovyy status osib, yaki berut uchast u spravakh pozovnoho provadzhennya: monohrafiya [Civil procedural legal status of persons involved in litigation: a monograph]. Kyiv: Atika. [in Ukrainian].

9. Bratus, S. N. (1950). Subyekty grazhdanskogo prava. Kurs sovetskogo grazhdanskogo prava [Subjects of civil law. The course of Soviet civil law]. Moscow: State Publishing House of Law Literature. [in Russian].

10. Derra, M. (2020). Advokatura v Germanii [Advocacy in Germany] <https://zakon.ru/Tools/DownloadFileRecord/23439> (2020, September, 27). [in Russian].

11. Zakon i Biznes (2018). [Law and Business (2018)]. Harantiyi advokatskoyi diyalnosti: YESPL naviv klyuchovi rishennya [Advocacy guarantees: The ECHR provided key decisions] <https://zib.com.ua/ua/print/131858-garantii_ advokatskoi_diyalnosti_espl_naviv_klyuchovi_rishenn.html> (2020, September, 27). [in Ukrainian].

12. Zakon pro advokaturu ta advokatsku diyalnist, 2012 (Verkhovna Rada Ukrayiny) [Law on Advocacy and Advocate Activity, 2012 (Verkhovna Rada of Ukraine)]. Holos Ukrayiny [Voice of Ukraine], 148-149, 14 Aug. [in Ukrainian].

13. Zakon pro bezoplatnu pravovu dopomohu, 2011 (Verkhovna Rada Ukrayiny) [Law on Free Legal Aid, 2011 (Verkhovna Rada of Ukraine)]. Ofitsiynyy sayt Verkhovnoyi Rady Ukrayiny. [Official site of the Verkhovna Rada of Ukraine] <https://zakon.rada.gov.ua/laws/show/3460-17/conv\#Text> (2020, September, 27). [in Ukrainian].

14. Zakon pro vykonannya rishen ta zastosuvannya praktyky Yevropeyskoho sudu z prav lyudyny, 2006 (Verkhovna Rada Ukrayiny) [Law on Execution of Decisions and Application of the Case Law of the European Court of Human Rights, 2006 (Verkhovna Rada of Ukraine)]. Ofitsiynyy sayt Verkhovnoyi Rady Ukrayiny [Official site of the Verkhovna Rada of Ukraine] <https://zakon.rada.gov.ua/laws/show/3477-15/conv\#Text> (2020, September, 27). [in Ukrainian].

15. Zakon pro derzhavnu reyestratsiyu yurydychnykh osib, fizychnykh osib-pidpryyemtsiv ta hromadskykh formuvan, 2003 (Verkhovna Rada Ukrayiny) [Law on State Registration of Legal Entities, Individual Entrepreneurs and Public Associations, 2003 (Verkhovna Rada of Ukraine)]. Holos Ukrayiny [Voice of Ukraine], 115, 24 June. [in Ukrainian].

16. Konstytutsiya Ukrayiny, 1996 (Verkhovna Rada Ukrayiny) [Constitution of Ukraine, 1996 (Verkhovna Rada of Ukraine)]. Ofitsiynyy sayt Verkhovnoyi Rady Ukrayiny [Official site of the Verkhovna Rada of Ukraine] <https://zakon.rada.gov.ua/laws/show/254\%D0\%BA/96-\%D0\%B2\%D1\%80/conv\#Text> (2020, September, 27). [in Ukrainian].

17. Nakaz pro zatverdzhennya Polozhennya pro tsentry z nadannya bezoplatnoyi vtorynnoyi pravovoyi dopomohy, 2012 (Ministerstvo yustytsiyi Ukrayiny) [Order on approval of the Regulations on free secondary legal aid centers, 2012 (Ministry of Justice of Ukraine)]. Ofitsiynyy sayt Verkhovnoyi Rady Ukrayiny [Official site of the Verkhovna Rada of Ukraine] <https://zakon.rada.gov.ua/laws/show/z1091-12/conv\#Text> (2020, September, 27). [in Ukrainian].

18. Nakaz pro zatverdzhennya Poryadku ta kryteriyiv zaluchennya orhanamy mistsevoho samovryaduvannya yurydychnykh osib pryvatnoho prava do nadannya bezoplatnoyi pervynnoyi pravovoyi dopomohy, 2012 (Ministerstvo yustytsiyi Ukrayiny) [Order on approval of the Procedure and criteria for involvement of local governments` legal entities of private law in the provision of free primary legal aid, 2012 (Ministry of Justice of Ukraine)]. Ofitsiynyy sayt Verkhovnoyi Rady Ukrayiny [Official site of the Verkhovna Rada of Ukraine] <https://zakon.rada.gov.ua/laws/show/z0987-12\#n15> (2020, September, 27). [in Ukrainian].

19. Nakaz pro zatverdzhennya Typovoho polozhennya pro ustanovu z nadannya bezoplatnoyi pervynnoyi pravovoyi dopomohy, 2012 (Ministerstvo Yustytsiyi Ukrayiny) [Order approving the Standard Regulations on the Institution for the Provision of Free Primary Legal Aid, 2012 (Ministry of Justice of Ukraine)]. Ofitsiynyy sayt Verkhovnoyi Rady Ukrayiny [Official site of the Verkhovna Rada of Ukraine] <https://zakon.rada.gov.ua/laws/show/z0474-12/conv\#Text> (2020, September, 27). [in Ukrainian].

20. Postanova Verkhovnoho Sudu u spravi № 559/1777/15-ts, 2018 (Verkhovnyy Sud Ukrayiny) [Resolution of the Supreme Court in the case № 559/1777/15-ts, 2018 (Supreme Court of Ukraine)]. Yedynyy derzhavnyy reyestr sudovykh rishen [Unified state register of court decisions]. <http://www.reyestr.court.gov.ua/Review/78627871> (2020, September, 27). [in Ukrainian].

21. Postanova u spravi № 161/4985/17, 2019 (Verkhovnyy Sud Ukrayiny) [Resolution in case № 161/4985/17, 2019 (Supreme Court of Ukraine)]. Yedynyy derzhavnyy reyestr sudovykh rishen [Unified state register of court decisions]. <http://www.reyestr.court.gov.ua/Review/81573955> (2020, September, 27). [in Ukrainian]. 
22. Postanova u spravi № 826/1781/17, 2019 (Verkhovnyy Sud Ukrayiny) [Resolution in case № 826/1781/17, 2019 (Supreme Court of Ukraine)]. Yedynyy derzhavnyy reyestr sudovykh rishen [Unified state register of court decisions]. <http://www.reyestr.court.gov.ua/Review/80854749> (2020, September, 27). [in Ukrainian].

23. Rabinovych, P. (ed.) (2019). Nezalezhnist i yurydychna vidpovidalnist suddiv yak harantiyi verkhovenstva prava [Independence and legal responsibility of judges as a guarantee of the rule of law]. Lviv: Spolom. [in Ukrainian].

24. Saley, Ye. A. (2020). Pravosposobnost yuridicheskikh lits po zakonodatelstvu Respubliki Belarus [Legal capacity of legal entities under the legislation of the Republic of Belarus], 140-146. Law.Bsu.By <https://law.bsu.by/pub/29/Salei_1.doc> (2020, September, 27). [in Russian].

25. Serova, O. A. (2010). Ponyatiye i vidy pravosposobnosti yuridicheskogo litsa [The concept and types of legal capacity of a legal entity]. Vestnik Samarskoy gumanitarnoy akademii. Seriya Pravo [Bulletin of the Samara Humanitarian Academy. Series Law], 1 (7), 72-87. [in Russian].

26. Zinchenko, S. A., Shapsulov, D. Yu., Korkh, S. E. (1999). Predprinimatelstvo i status yego subyektov $v$ sovremennom rossiyskom prave [Entrepreneurship and the status of its subjects in modern Russian law]. Rostov-on-Don. [in Russian].

27. Spasybo-Fatyeyeva, I. (2014). Yurydychni osoby za Tsyvilnym kodeksom Ukrayiny [Legal entities under the Civil Code of Ukraine]. Pravo Ukrayiny [Law of Ukraine], 2, 70-79. [in Ukrainian].

28. Tsyvilnyy kodeks Ukrayiny, 2003 (Verkhovna Rada Ukrayiny) [Civil Code of Ukraine, 2003 (Verkhovna Rada of Ukraine)]. Vidomosti Verkhovnoyi Rady Ukrayiny [Information of the Verkhovna Rada of Ukraine], 40, 3. [in Ukrainian].

29. Yurkevych, Yu. M. (2017). Dohovirni formy obyednan fizychnykh ta yurydychnykh osib u tsyvilnomu pravi Ukrayiny [Contractual forms of associations of individuals and legal entities in the civil law of Ukraine]: Dysertatsiya na zdobuttya naukovoho stupenya doktora yurydychnykh nauk [Dissertation for the degree of Doctor of Laws]. Lviv: Lvivskyy natsionalnyy universytet imeni Ivana Franka. [in Ukrainian].

30. Case of Doran v Ireland (Application no. 50389/99). 31 July 2003 (European Court Of Human Rights). Cour Européenne Des Droits De L'homme [Official site of the European court of human rights] <https://hudoc.echr.coe.int/fre\#\{"itemid":["001-61277"]\}> (2020, September, 27). [in English].

31. Case of Caic' and others v Croatia 22014/04, 2008 (European Court Of Human Rights). Cour Européenne Des Droits De L'homme [Official site of the European court of human rights] <https://hudoc.echr.coe.int/rus\#\{"itemid":["001-87640"]\}> (2020, September, 27). [in English].

32. Postanova u spravi № 21-416vo08, 2008 (Verkhovnyy Sud Ukrayiny) [Resolution in the case № 21-416vo08, 2008 (Supreme Court of Ukraine)]. Yedynyy derzhavnyy reyestr sudovykh rishen [Unified state register of court decisions]. <http://www.reyestr.court.gov.ua/Review/3134164> (2020, September, 27). [in Ukrainian]. 